\title{
Redlining Revisited: Mortgage Lending Patterns in Sacramento 1930-2004
}

\author{
JESUS HERNANDEZ
}

\begin{abstract}
Despite decades of government reform, the American housing credit system continues to mirror long-standing patterns of racial segregation and inequality. Consistent with this trend, the current housing crisis reveals an unusually high concentration of subprime mortgage activity and property foreclosures in non-white residential settlements across the nation. Given the generally accepted premise of market neutrality, this case study of lending patterns in Sacramento, California, questions why US housing market exchanges continue to produce racially disparate outcomes and seeks to identify the ideological practices in which race is deployed, informs state and private economic action and shapes contemporary credit market practices.
\end{abstract}

\section{Introduction}

For quite some time, housing activists and scholars have documented the concentration of subprime loans in US neighborhoods highly populated with non-white residents (Bradford, 2002; ACORN, 2004), and the targeting of non-White borrowers by subprime lenders (Immergluck and Wiles, 1999; Wyly et al., 2006). The racial and geographic concentration of subprime loans suggests that contemporary lending patterns may be repeating the punitive mortgage redlining practices of past years that aided the decline of many inner cities throughout the US. Squires (2005) notes that the exploitative terms of subprime loans and their concentration in non-white neighborhoods may be just as harmful as the race- and place-based withdrawal of financial services previously imposed on formerly redlined neighborhoods. This 'reverse redlining' referred to by Squires, and the accompanying concentration of mortgage defaults and foreclosures, suggests a longstanding relationship between geography, race and contemporary housing and credit markets.

Subprime lending can be simply described as mortgage credit with interest rates substantially higher than those for conventional financing. Generally, subprime lenders target borrowers who have poor credit histories with mortgage products that bring an unusually high yield to lending institutions and their investors. Such excessive profit margins, realized through a pricing structure that includes periodic interest rate increases, prepayment penalties and balloon payments, place a heavy financial burden on borrowers. Consequently, subprime borrowers are 6-9 times more likely to be in

The author thanks Manuel Aalbers, Bruce Haynes, Fred Block and Elvin Wyly for comments on previous drafts of this article. The author also thanks Richard Marciano and the Testbed for Redlining Archives of California's Exclusionary Spaces (T-Races) project for access to maps and records of the Federal Home Loan Bank Board, National Archives: Record Group 195. Thanks also to Patricia Johnson at the Sacramento Archives and Museum and Collection Center. The author claims responsibility for all errors and opinions contained in this article. 
foreclosure (Renuart, 2004; Schloemer et al., 2006; Girardi et al., 2007). Because homeowner equity remains the largest component of wealth for low-income and nonwhite households in the US (Oliver and Shapiro, 1995; Conley, 1999), subprime lending, with its higher propensity for foreclosures, undermines and discourages the wealthbuilding capacity of affected homeowners and targeted communities (Farris and Richardson, 2004); a process that mirrors the disinvestment practices and the loss of wealth-building opportunities from past episodes of redlining. Contemporary lending patterns in cities, therefore, continue to reflect the uneven distribution of wealth in US communities while giving local racialized geographies an intergenerational quality. Consequently, the concentration of loans with high foreclosure rates brings a social and financial vulnerability to targeted neighborhoods, leaving them highly unstable in times of economic crisis.

I use the county of Sacramento, California, an area populated by 1.2 million residents at the time of the 2000 Census, as the site to examine conditions that led to increased subprime loan activity and its concentration in racialized space; geography created by the historical process of organizing space along racial categories (Iglesias, 2000; Haynes, 2001). Four key practices established the racial geography that now defines the Sacramento area: the explicit use of racially restrictive covenants, the informal enforcement of those covenants, central city urban renewal programs, and mortgage redlining. Preliminary observations suggest that subprime loan activity is highly concentrated in neighborhoods with high ratios of non-whites shaped by these longstanding practices of housing segregation. Moreover, housing industry information service providers, e.g. RealtyTrac, report that these neighborhoods currently experience some of the highest mortgage default and foreclosure rates in the US. These observations suggest a tendency to racialize the flow of housing finance capital and that housing finance capital flows are geographically related to historically racialized housing policies. Sacramento also provides a typical example of urban processes such as segregation and sprawl that shape the social and physical landscapes of cities throughout the US. For these reasons, Sacramento provides an opportunity to understand contemporary housing credit markets as part of a larger historical process that takes form socially as well as spatially.

Finally, the 'greenlining' of credit-starved neighborhoods (see Newman, 2009, this issue) signals a major change in housing finance policy and demonstrates how housing credit transforms historically undercapitalized sites of racial segregation to new sites of capital accumulation. This conversion of racialized space from a place of exclusion to a place of extraction is critical to understanding the changing role of race in the post-Civil Rights economy. This study, therefore, investigates how the fusion of both explicit and supposedly race-neutral or 'colorblind' housing market practices set the stage for present-day subprime mortgage activity in the city of Sacramento.

\section{Analytical lens}

I focus on the role of capital in urban inequality, the role of the state in market (re)organization, and the role of human agency and social interaction that guide policy and decision-making to investigate the deep-rooted patterns of spatial and racial inequality in the US. The merging of these three axioms provides a powerful analytical lens in which to view the nexus of race and economy as a historical process that utilizes racial segregation to advance capital accumulation.

Harvey (1985) contends that space is produced actively with the primary force behind spatial production being capital accumulation. The process of uneven urban development is the result of different levels of return on investment in specific locations. Therefore, the market in land and buildings orders urban phenomena and determines what city life can be (Logan and Molotch, 1987: 17). Consequently, the logic of profit-making governs 
spatial development with real estate markets being one of the key ways in which cities and regions grow (Gottdiener, 1994).

But we also know that markets do not operate independently as governments assume an active role in establishing the conditions for property exchange and shaping market organization, market activity and market outcomes (Campbell and Lindberg, 1990; Fligstein, 1996). Gotham (2006) informs us that the conversion of real estate, a fixed immobile asset, to a standardized transparent financial instrument exchangeable through global markets largely remains a product of state action. Housing credit, through the process of securitization, is a fundamental part of this conversion and reflects the state's active involvement in the creation of markets, market products and market demand. In this manner, housing credit extends the way in which the state oversees exchanges in the market place. The subprime loan market, therefore, is an important and telling example of the government's expanding role in the conversion of space to sites for capital accumulation.

We know that real estate market activity is not solely a function of private enterprise because it involves direct governmental action in many ways. From regulating property rights to facilitating the movement of capital flows between regions, the state's active role suggests that the creation of spatial environments reflects decisions based on the social, political and cultural dimensions of our society (Gottdiener and Hutchinson, 2006). Although individuals participate in markets, Squires (2002) correctly notes that public policy and the private sector constrain individual choice and guide market operations. Hence, we can see that changes to the urban environment are both socially and politically generated and mediated (Smith, 1988; Squires, 1989).

If we can consider economic action as socially situated (Granovetter, 1985; Granovetter and Swedberg, 1992), then the above theoretical notions provide important clues to investigating the role of human agency in the use of racial hierarchies to valuate space and in allocating housing credit. These clues provide an understanding of the relationship between the social constructions of race and economy in the US, how they inform each other, and how they interact at multiple scales, i.e. spatial (local, regional, national, global) and social (individual, group, institution, society). Although these scales are distinct, they possess dialectical relations among them that place the social critique at the center of economic analysis (Pulido, 2004). This case study, then, focuses on how social factors directly influence the price of space (Logan and Molotch, 1987) while legitimizing unequal access to market opportunities (Smith, 1988). Through this lens, US housing markets can be seen as social constructions that reflect and aid in the managing of social relations in the city.

I follow the lead of Gotham (2002: 3) who situates the origins and growth of racial residential segregation within 'the broader processes of capitalist development, the changing dynamics of real estate activities and investment, and federal housing programs'. This allows us to see how housing inequality takes form through a partnership between politicians who shape public policy and the private sector that benefits from such a policy, a partnership that does not always work equally for all urban residents. This partnership between polity and business comes at a great cost to urban neighborhoods, since they rarely see the positive effects of housing policy and privatism but rather the uneven economic development so typical of cities today (Squires, 1989; 1994).

In Gotham's analysis, the uneven development and residential segregation that take place concomitantly in cities can be viewed as 'analogous, reciprocally related, and mutually constitutive of each other' (Gotham, 2002: 3). This view insists on acknowledging the linkage between race and markets. Accordingly, my analysis of subprime lending also considers how contemporary market structures and outcomes are connected to historical events and processes of stratification. We can therefore view the US housing finance market as a racialized structure that produces racial inequity through specific practices, mechanisms and social relations (Bonilla-Silva, 1997; Dymski, 2007). 
Historically, race has long been associated with property value in the US. During the 1920s, real estate professionals tied property values to color as a means of legitimizing racial exclusion and protecting racial boundaries. Realtors used racial categories in property valuation and promoted differential treatment as an industry standard during an early and critical stage of US suburban growth (Helper, 1969). Working from the notions that the racial integration of a neighborhood can lead to a very rapid decline in property value (McMichael and Bingham, 1928), and that the value of land partially depends on the racial heritage of the people living on it (Babcock, 1932; Hoyt, 1933), New Deal housing finance programs institutionalized the use of racial categories in assigning space and allocating social goods (Freund, 2006).

Although New Deal housing finance programs were important in modernizing the mortgage industry, two federal loan requirements that promoted segregation are significant for this analysis. During the period 1930-50, New Deal loan programs mandated the use of racially restrictive covenants that prohibited non-white occupancy of homes in white neighborhoods, and mortgage redlining prohibited the use of federally insured mortgages in racially integrated neighborhoods (Freund, 2006). Under the pretext of reducing the risk exposure to lending institutions, the Federal Housing Administration (FHA) systematically excluded non-whites from obtaining home loans and openly used racial categories to exclude minorities from suburban areas of growth (Stuart, 2003; Freund, 2006). Hence, the use of race to determine eligibility for housing credit became both an accepted and expected business practice.

Acknowledging the historical racialization of US housing markets at an early and critical stage in the development of US cities helps us understand how social context informs the construction of risk as a factor in accessing housing credit (Stuart, 2003). Stuart explains that race-based differential treatment in housing was simply reduced to a matter of risk assessment and, as a result, an acceptable business practice formalized under the pretext of protecting investment capital from perceived risk. Risk management was translated into a mandate for exclusion achieved through the use of boundaries to organize and guide market access. It is this socially constructed relationship between race and risk that remains the root of historically disparate housing opportunities in the US. Consequently, race maintains a powerful role in the shape and opportunities of US cities, remains an integral factor in urban development, and must be placed at the center of serious urban analysis (Feagin, 1998).

I use this analytical lens to investigate the pre-existing conditions that contributed to concentrating subprime loans in specific localities and within specific populations. I examine how these conditions work over time to contribute to the current housing crisis in the US and reproduce the geography of racialized space. Despite decades of housing finance reform, which have managed to improve levels of minority homeownership and access to mortgage credit, inequities in housing credit somehow remain concentrated in those geographies characterized by past forms of deliberate racial segregation. Therefore, this study of contemporary housing credit markets in Sacramento can provide some insight into an emerging intergenerational quality of race-based housing inequity and its potential impact on neighborhoods in crisis.

\section{Method and data}

I use a case study approach to investigate the concentration of subprime loans within areas predominantly populated by non-white residents in Sacramento. Yin (1994) recommends the case study approach when research questions are more explanatory and are likely to deal with operational links needing to be traced over time. Moreover, the case study provides an ability to deal with the full variety of evidence needed to explain why certain phenomena take place over time and within a particular place (Creswell, 1998). The case study method, therefore, has particular advantages when investigating 
the convergence of local and external forces and how they interact to shape social and physical landscapes.

Using multiple data sources in this case study helps to properly contextualize the settings in which the subprime loan industry operates in Sacramento. I rely on original Home Owners Loan Corporation (HOLC) Residential Security maps and appraisal data from 1938, census data from 1950 to 2000, interviews with residents, and local government records to identify historically race-based market practices. I utilize a series of oral histories captured by community activists to document racialized housing practices of real estate professionals in Sacramento from 1950 to 1980. Newspaper articles, County records and conversations with real estate agents and escrow officers were used to compile a preliminary list of census tracts with racially restrictive covenants. The number of tracts with such covenants identified by my research appears conservative. The Sacramento County Assessor estimates over 2,500 subdivisions with such covenants (Magagnini, 2005). Although these tracts account for a small portion of what is now a large metropolitan area, at the time restrictive covenants were imposed they represented important areas of economic and residential expansion during the post-war suburban boom and reflected the use of racial categories in designating neighborhood boundaries. The geography of these restrictions aids our understanding of how racial categories impacted urban planning and housing finance decisions, and influenced patterns of residential settlement over time. However, an exact accounting of the use of these covenants throughout the county requires a more comprehensive research effort. The possibility exists that any failure to identify all tracts with restrictive covenants may unintentionally skew the findings of this research.

I use the 2004 Home Mortgage Disclosure Act (HMDA) data for Sacramento County consisting of 273,286 loan applications for the calendar year. The collected information includes loan type, loan amount, property location, loan disposition, loan fees and applicant demographic information required for federal monitoring of lending activity throughout the US. Like previous research on subprime lending, I use the Department of Housing and Urban Development's (HUD) annual list of HMDA reporting lenders that specialize in subprime loans to identify subprime lenders and their activity in the Sacramento County. Although problems exist with the HUD subprime lender list that may result in understating the actual influence of the subprime market (Lax et al., 2004; Calem et al., 2004), a review of the pertinent literature indicates that the HUD subprime lender list, when used with HMDA data, still represents the most widely accepted method in terms of identifying subprime loan activity. The year 2004 marks the peak of subprime loan activity in Sacramento. ${ }^{1}$ Moreover, subprime loans originated in this year are for the most part the vintage of toxic loans that brought about the dramatic increase in foreclosures that took place in 2007. For these reasons, I focus on 2004 HMDA data. Finally, I compare ratios of subprime activity by census tract with the geographies of restrictive covenants and redlining.

The remainder of this article is organized as follows. Three sections discuss critical periods of change in the housing credit industry. The period 1930-50 reveals the initial period of redlining initiated by FHA and the official use of racial categories in determining access to housing credit that established racial segregation as an accepted practice in US cities. The period 1950-80 is marked by the effects of urban renewal programs, highway construction projects, the resulting mass relocation of non-White communities, the subsequent redlining of neighborhoods integrated as a result of these projects, and the actions of local real estate professionals. The period 1980-2004 brings to the fore the emerging subprime loan market and the concentration of these

1 HMDA raw data for 2003-06 shows that the peak year for subprime activity in Sacramento was 2004. HMDA only includes those loans subject to Community Reinvestment Act (CRA) reporting requirements. Many subprime lenders do not fall under CRA reporting requirements. Therefore, HMDA data does not include a significant number of subprime loans originated during this period. 
loans in racialized space created by national housing policy and private actions. For each period, I describe the role of national housing policy in creating conditions necessary for the subprime mortgage market to take hold in Sacramento. These sections are followed by a cartographic summary of 2004 HMDA data and concluding remarks.

\section{Redlining phase I: racializing housing credit (1930-50)}

Racially restrictive covenants in Sacramento took root in the 1920s when local developer J.C. Carly subdivided farmland for residential development just south of the original Sacramento Township. Carly, one of the founding fathers of the local real estate board, followed in step with the National Association of Real Estate Boards (NAREB), which, during this period, mandated real estate agents to honor restrictive covenants and provided local real estate boards with templates for drafting covenants that created and maintained segregated neighborhoods (Helper, 1969). County Assessor records show that Carly's residential developments used racial covenants and began a trend of overt discriminatory institutional actions to establish separate residential spaces for whites. Hence, property value in Sacramento became associated with race as early as 1920 .

New Deal housing programs, initiated in the 1930s, subsequently mandated the use of racially restrictive covenants as a condition of loan approval (Jackson, 1985) to avoid introducing 'incompatible' racial groups into white residential enclaves (Freund, 2006). Developers of new suburban tracts in elite neighborhoods used racial covenants as a means to attract buyers as developers advertised the use of 'wise restrictions' along with FHA Title II financing to assure buyers of the safety of their investment (Isidro, 2005). Since FHA financing aided both construction and sales of new homes, developers of new communities in Sacramento during this period eagerly complied with FHA mandates for racial restrictions on residency by excluding blacks and other non-whites from housing tracts in elite neighborhoods and areas adjacent to the northern part of the city undergoing rapid growth. The use of FHA loan programs during this period institutionalized the practice of racial segregation in new suburban housing tracts throughout the city and county. ${ }^{2}$

By 1950 , the distinct dual geographies of the city were clearly evident. Racial restrictions on Sacramento residential real estate controlled the location of ethnic groups according to a perceived risk on property values. Segregation, therefore, became a method of risk containment sanctioned by federal housing credit policy as necessary to maintain the value of white residential space. Consequently, a racial divide grew that would eventually concentrate non-Whites in older, "non-restricted' residential tracts.

During this same period, federal housing policy also restricted the flow of housing capital into racially integrated neighborhoods (Jackson, 1985). In Sacramento, the HOLC Residential Security Map of 1938 identified the Sacramento neighborhood known as the 'West End', the northwest area of downtown Sacramento between the State Capitol building on $10^{\text {th }}$ Street to the east and the Sacramento River to the west, as the location that presented the primary risk to lenders (see Figure 1). The redlining of the West End severely altered the property owners' ability to finance repairs and maintain

2 During the late 1930s, the bulk of mortgage activity in Sacramento consisted of new construction loans. Banks, through the use of federal Title II loans, supplanted individuals as the principal mortgage lenders in the area and dominated mortgage origination activity. In 1938, almost $80 \%$ of mortgages for the top 5 banks and trust companies in Sacramento were Title II loans. See Summary, HOLC Survey of Sacramento, California by the Division of Research and Statistics Field Report dated 2 December, 1938 (source: Testbed for Redlining Archives of California's Exclusionary Spaces [T-Races]). 


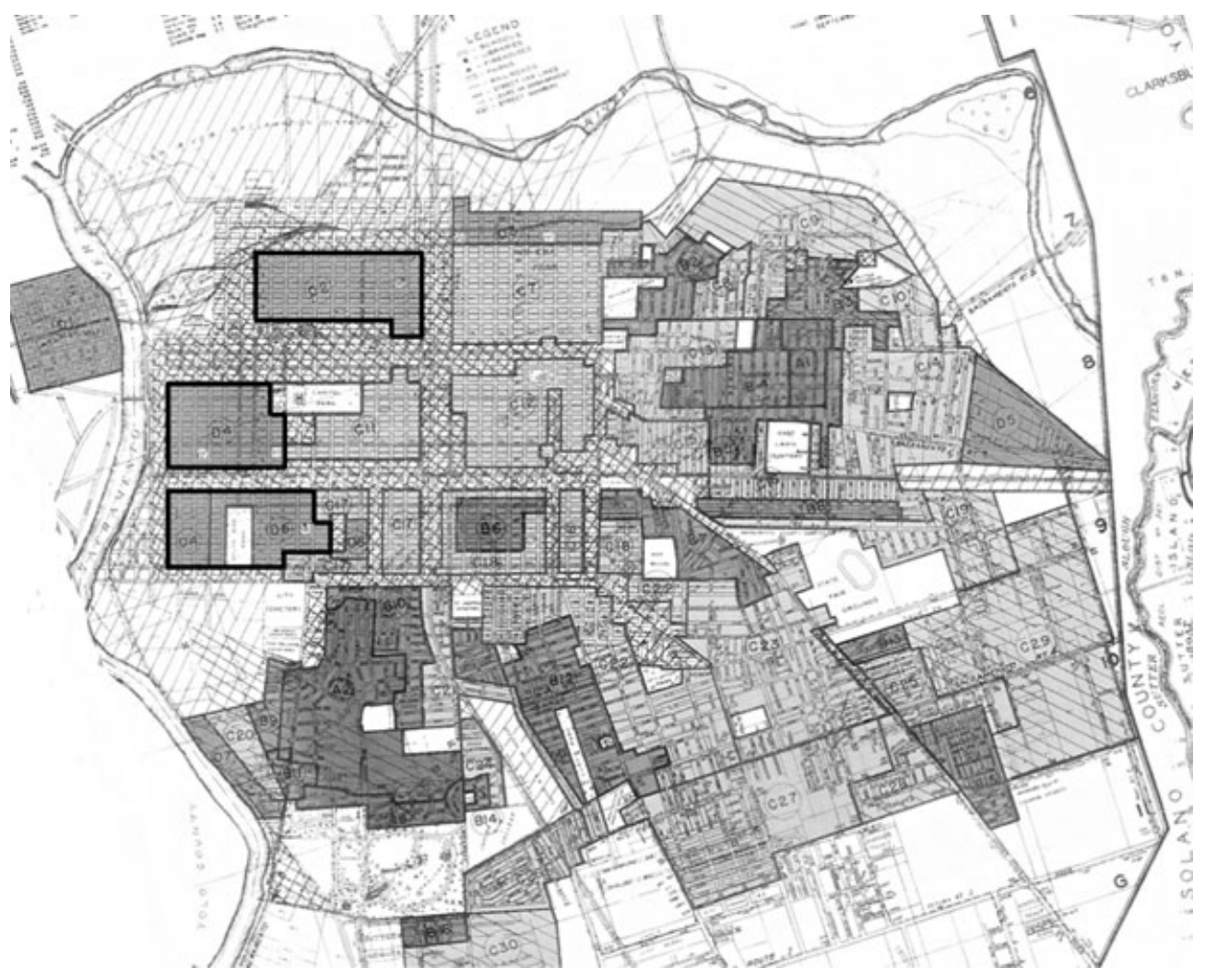

Note: 1938 Home Owners Loan Corporation Residential Security Map of Sacramento. Redlined areas of the West End are identified by the highlighted borders

Figure 1(a) Comparison of 1938 Sacramento Residential Security Map and 1949 Sacramento Redevelopment Survey Area (source: Federal Home Loan Bank Board, National Archives: Record Group 195; map courtesy of T-Races [Testbed for the Redlining Archives of California's Exclusionary Spaces])

their property. ${ }^{3}$ Moreover, with redlining preventing buyers from obtaining financing, West End property owners were unable to participate in conventional real estate market practices. $^{4}$

The inability of West End property owners to participate in normal market exchanges led to a drastic decline in the value of redlined real estate. From 1938, the beginning of West End redlining by the FHA, to 1949, property in Sacramento experienced a $46 \%$ increase in value. But during this same period, redlined property decreased in value by 30\% (Sacramento City Planning, 1950). Clearly, the city's racialized geography took shape around the ability to participate in housing markets. While the FHA actively protected the property rights of the new homogeneous white suburban communities, it prohibited non-whites access to wealth accumulation opportunities gained only through housing credit and homeownership.

3 HOLC appraisal worksheets for 1937 identified areas of the city where mortgage credit was difficult to obtain, thus indicating that some informal redlining by lenders occurred in Sacramento prior to the creation of the Residential Security Maps (source: T-Races). The formalizing of race-based underwriting guidelines by the FHA provided real estate professionals with organized race-based policies that intensified redlining practices during this period when the primary source of mortgage credit in the city shifted from individuals to federally regulated banks via the use of Title II loans.

4 See also Sacramento City Planning (1950). 


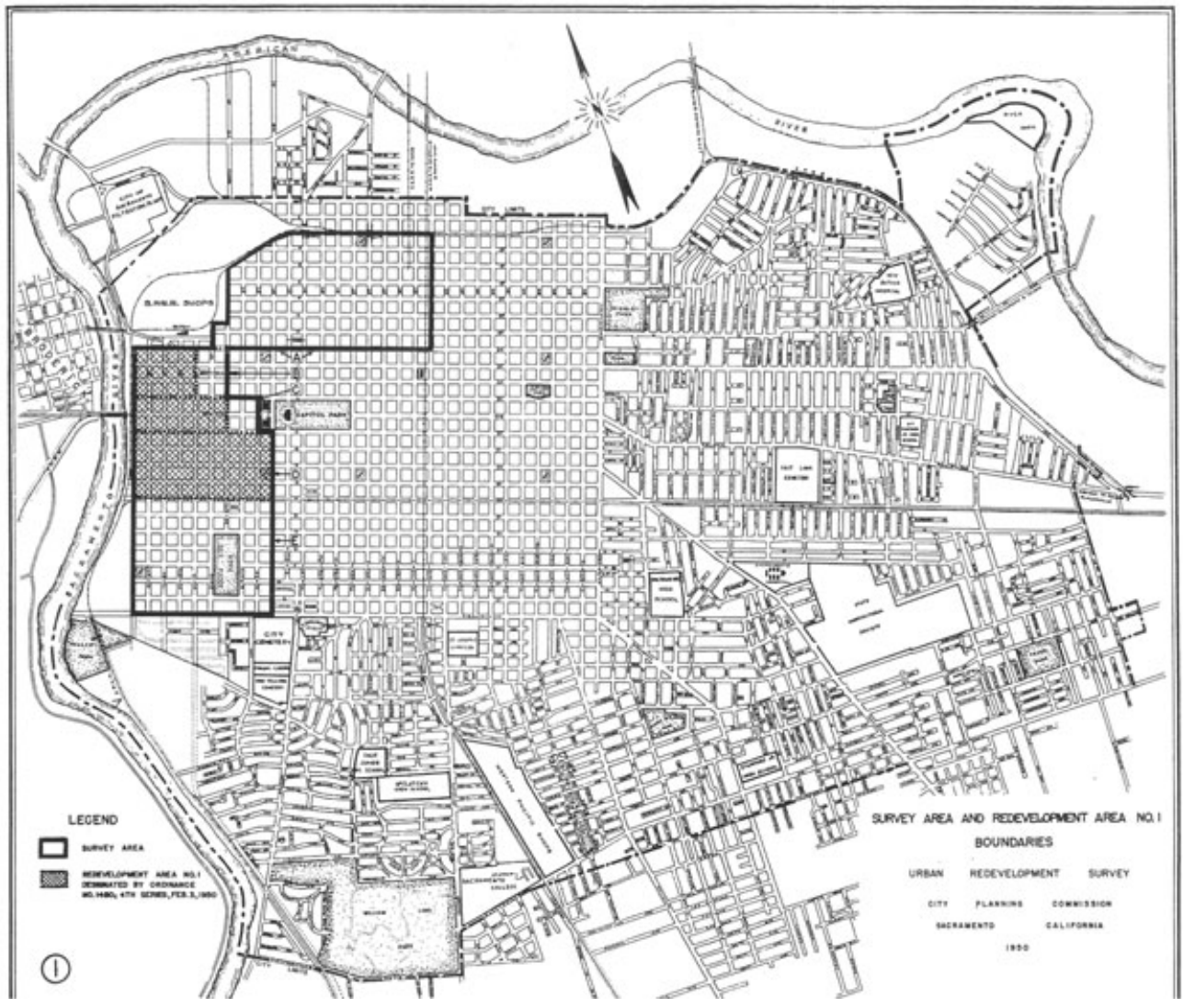

Note: Highlighted borders identify West End areas impacted by urban renewal programs and are strikingly similar to areas redlined by FHA in the above Residential Security Map

Figure 1(b) 1949 Redevelopment Survey Area Map of Sacramento (source: Sacramento City Planning, 1950)

West End property owners resorted to converting homes into multiple units and obtaining more rents to compensate for lost value (ibid.). This transformed a neighborhood designed for single-family occupancy to one of conversions for multiplefamily tenant use and accelerated the deterioration of the area's residential quality.

City redevelopment planning documents indicate that the greatest concentration of non-whites in the city were in the West End. Some city blocks in the West End were reported as having 90-99\% of dwelling units occupied by non-whites in 1940, a fact that planning documents attributed in part to the housing restrictions imposed by racial restrictive covenants (ibid.). These strategically enforced racial restrictions on residency led absentee landlords to capitalize on market constraints by renting converted units to non-Whites unable to leave the neighborhood (ibid.). Hence, the enforcement of restrictive covenants in the city for the most part contained non-white residents within the boundaries of the West End.

Adding to the racial concentration in the West End was the signing of Executive Order 8802 by President Roosevelt in 1942 that allowed blacks to work in military installations and initiated a flow of black labor to Sacramento that increased with each episode of military involvement. Another factor was the importing of Mexican labor via the Labor Importation Program of 1942, better known as the Bracero Act, to compensate for labor shortages caused in part by Japanese internment during the second world war. Originally 
intended for agricultural support, Braceros found themselves in a number of varied industries as agriculture capitalized on improvements in transportation technology. When farmers began to transport products throughout the nation, Mexican labor soon migrated to the city to meet the demands of local food processing canneries, making up almost 50\% of all employment in Sacramento canneries during the 1940s. An expanding railway system placed additional demands on Mexican labor and Sacramento's Southern Pacific rail yards located on the northern border of the city contributed to the large Mexican presence in the West End (Avella, 2003). Census data provides further evidence of how racial covenants and redlining helped shape city neighborhoods. By 1950, almost $70 \%$ of the city's minority population was located in the West End with $87 \%$ of the city's Mexican residents, $75 \%$ of the city's Asian population, and $60 \%$ of the city's black population residing there.

During this period, the combination of restrictive covenants and controls on housing credit concentrated non-white residents in the redlined West End while steadily reducing property values. As improvements to transportation technology and suburban growth set in motion the movement of business and employment to the city's outer rings, this state-sponsored decline now set the stage for the devastating urban renewal phase of city building and the forced exodus of entire non-white communities from the West End.

\section{Redlining phase II: redevelopment and relocation (1950-80).}

The Federal Housing Act of 1949 focused on eliminating substandard living conditions through the clearance of slum areas and provided federal subsidies for cities attempting to remedy serious housing shortages. The Act was originally centered on improving the housing stock in 'blighted' communities, but amendments to it in 1954 changed the approach to urban renewal, weakening the requirement for predominantly residential construction in redevelopment sites (Gelfand, 1975). Despite strong objections from residents, Sacramento city planners seized the opportunity to alter proposed housing plans that initially accommodated low-income minority residents and turned to private commercial development as the mechanism to generate tax dollars and encourage the return of business to the West End. ${ }^{5}$

Public highway construction also affected Sacramento's physical and social geography and became the perfect complement to redevelopment. Federal transportation funds provided up to $90 \%$ of the construction costs for expressways that connected the racially homogenous suburban tracts in the northeast, eastern and southwest parts of the county to the redevelopment projects that brought employment and commercial centers to the West End. ${ }^{6}$ But the placement of these roads also created a physical barrier between neighborhoods with restrictive covenants and areas soon to be racially integrated by forced West End migration. These massive transportation thoroughfares, along with urban renewal plans, would accelerate changes to the city's racial landscape and ultimately the way Sacramentans would organize their lives and communities.

Figure One shows how urban renewal sites, identified by the black boundary in the Urban Redevelopment Survey Map for Sacramento in 1949, were located in precisely the same areas previously redlined by the FHA in the 1938 Residential Security Maps.

5 Local residents actively resisted West End redevelopment and organized a public awareness media campaign that resulted in voters defeating Proposition ' $B$ ', a bond proposal to finance the first stage of West End redevelopment (see series of paid political advertisements in The Sacramento Union, 21-31 October 1954). Despite the defeat of Proposition 'B' by voters on 2 November 1954, city council members subsequently approved the sale of tax allocation bonds to proceed with redevelopment plans (see 'Land Purchase in Blight Area is Set to Begin', The Sacramento Bee 8 August 1956).

6 See the National Interstate and Defense Highway Act of 1956. 
The switch in urban renewal plans from affordable housing to commercial development required the eviction of thousands of West End residents occupying redlined space. Consequently, these projects triggered an immediate need for affordable housing for those exiled from the newly created Redevelopment Survey Area.

Other national events also altered the racial mix of Sacramento's population and intensified the already urgent housing need of non-whites. The military build-up in response to the Korean and Vietnam Wars brought a new civilian and military workforce of approximately 25,000 to Sacramento's three military installations. Black employees constituted $10 \%$ of this new workforce (Mueller, 1966). Bracero labor continued to flow into the city beyond the official end of the program in 1964. Finally, the expansion of statewide administrative agencies during the 1960s, now centralized in newly constructed state office buildings in the redeveloped West End, triggered a sudden increase in non-white employment opportunities with the State of California. The strict enforcement of new employee discrimination laws provided access to employment for non-whites who now sought new housing opportunities beyond segregated space.

Together, these politically produced market pressures threatened the homogeneous quality of traditionally restricted neighborhoods throughout the Sacramento area. The demand for housing now included approximately 2,500 black households from military installations and another 3,000 blacks residing in the Redevelopment Survey Area and in the path of the W/X Freeway Interchange. Another 4,900 non-whites (predominantly Asian) and 3,500 Mexican residents classified as White Spanish Surname in the 1950 US Census also resided in the Redevelopment Survey Area. The combination of military involvement, migrant labor and government-sponsored construction projects that pushed non-whites out of the West End brought an immediate need to house thousands of non-white residents in a city actively engaged in, and shaped by, segregationist housing policies.

By the late 1950s, residents in the path of West End renewal and freeway construction projects reported the push by landlords and the city to relocate. The potential spillover to white neighborhoods threatened the homogeneity of restricted suburban space and prompted the informal actions of realtors and homeowners to protect established racial boundaries. ${ }^{7}$ Accordingly, the period 1960-67 shows housing market principals engaged in organized housing segregation.

The demand for suburban housing by non-whites revealed a resistance on the part of local developers, real estate professionals and property owners to open traditionally white housing tracts to non-white buyers. Racial steering and the refusal to sell or rent to non-whites by real estate professionals and property owners, a direct response to increased non-white housing demands, effectively halted integration of white neighborhoods. Using surveys, housing audits and oral histories, local housing activists such as the Sacramento Committee for Fair Housing documented discriminatory actions of realtors who routinely discouraged and denied purchase offers from non-whites attempting to move into new suburban tracts in Land Park and in northeast Sacramento such as Arden and Carmichael (Duff, 1963). These efforts helped activists shift protest strategies from the streets to the legal arena. Also, over $90 \%$ of the rental market in the area remained closed to non-whites (Mueller, 1966). Non-white military personnel were forced to live in predominantly low-income, non-white communities following multiple refusals from property managers restricting access to housing in white neighborhoods (Mueller and Crown, 1965). Finally, realtors and property managers openly organized to overturn fair housing laws that prohibited racial discrimination in property sales and

7 See, for example, Ming v. Horgan, et al. (Calif. Super. Ct., Sacramento Co., \#97130), where the Court clearly recognized and spelled out the various methods of consistent discrimination used by area subdividers, owners, builders and real estate agents in the absolute prohibition of Negroes from buying new housing in the area. The Court ruled that, as recipients of federal governmental assistance through FHA and VA financing, defendants were required not to flout the federal policy of equal rights established in Brown v. Board of Education. 
rentals. ${ }^{8}$ These unconcealed, organized and deliberate acts of protecting racial boundaries helped maintain the segregated geographies created by restrictive covenants despite the groundbreaking federal and state fair housing laws of the 1960s.

However, residential tracts without restrictive covenants reflected a distinctly different racial composition. When urban renewal projects pushed non-whites out of the West End, realtors, property managers and private property owners directed the flow of non-white residents who quickly filled available housing units in older racially unrestricted neighborhoods. Census data for the period 1950-70 provides us with the best indication of how quickly redevelopment and racial restrictions can radically alter the urban landscape. As the first stage of downtown redevelopment neared completion, the percentage of non-whites in the West End dropped remarkably from $42.6 \%$ in 1950 to $5.4 \%$ in 1970. But in Oak Park for example, a neighborhood without restrictive covenants located less than three miles southeast of the West End, the exact opposite occurred. In 1950, 6.5\% of the neighborhood's residents were non-white. By 1970, non-whites made up close to $48 \%$ of Oak Park's residents. While Oak Park experienced drastic changes to its population, census data show that the adjacent racially restricted neighborhoods remain consistently homogeneous to this date.

Fears of high risks for lenders, based on the area's rapidly changing demographics, led to a systematic disinvestment by financial institutions from older inner-city communities, now integrated as a result of West End migration, and initiated their eventual decline. With access to mortgage capital still contingent upon borrower racial characteristics and neighborhood racial composition, the rapid ethnic shift in Sacramento's population brought concern to local mortgage lenders. Interview data show that redlining occurred in neighborhoods that absorbed urban renewal emigrants and coincided with the escalation of redevelopment activities in Sacramento. One informant, a resident of Oak Park since the 1930s, confirms the practice of redlining in the neighborhood while discussing the city's housing problems of the 1950s:

But what they, you know back then when I was a young man, they had something called the red liners. See, yeah, see and blacks couldn't buy out in this area. So what they did, a black would get a white person to get the home for them, and then they would move in, then they would somehow take the title later.

Confirming the rise of redlining in Sacramento, property owners looking to sell homes to non-whites navigated around the lack of available financing in redlined areas by using installment contracts that gave physical possession to buyers but kept legal ownership in the name of the seller. One former West End resident describes her relocation to Oak Park in 1957.

We were lucky to find our house. We rented a small house in back of our landlord's house on $3^{\text {rd }}$ Avenue. When she evicted a renter from the house she owned next door, we asked her if we could buy it. She called her attorney who wrote up some kind of contract and we made payments right to her. I don't remember seeing any paperwork until we paid the house off. Then she sent us the papers that said we owned the house ... We bought our second house on $11^{\text {th }}$ Avenue the same way.

8 The California Real Estate Association and the California Apartment Owners Association formed the Committee for Home Protection to sponsor 'Proposition 14' in 1964, a statewide referendum to overturn the fair housing laws contained in the Rumford Act of 1963. The Sacramento Apartment House and Property Owners Association, along with the Sacramento Real Estate Board actively supported the committee's efforts (Cain, 1964; Mueller,1966; see also Sacramento Association of Realtors Archives - minutes from various executive staff meetings from 1963 through 1966). Sixty-two percent of Sacramentans voted in favor of Proposition 14 (source: Supplement to Statement of Vote, State of California General Election November 3,1964). The US Supreme Court later overturned this Proposition (see Reitman v. Mulkey, 387 US 369, 87 S.Ct. 1627, 18 L.Ed.2d 830 (1967). 


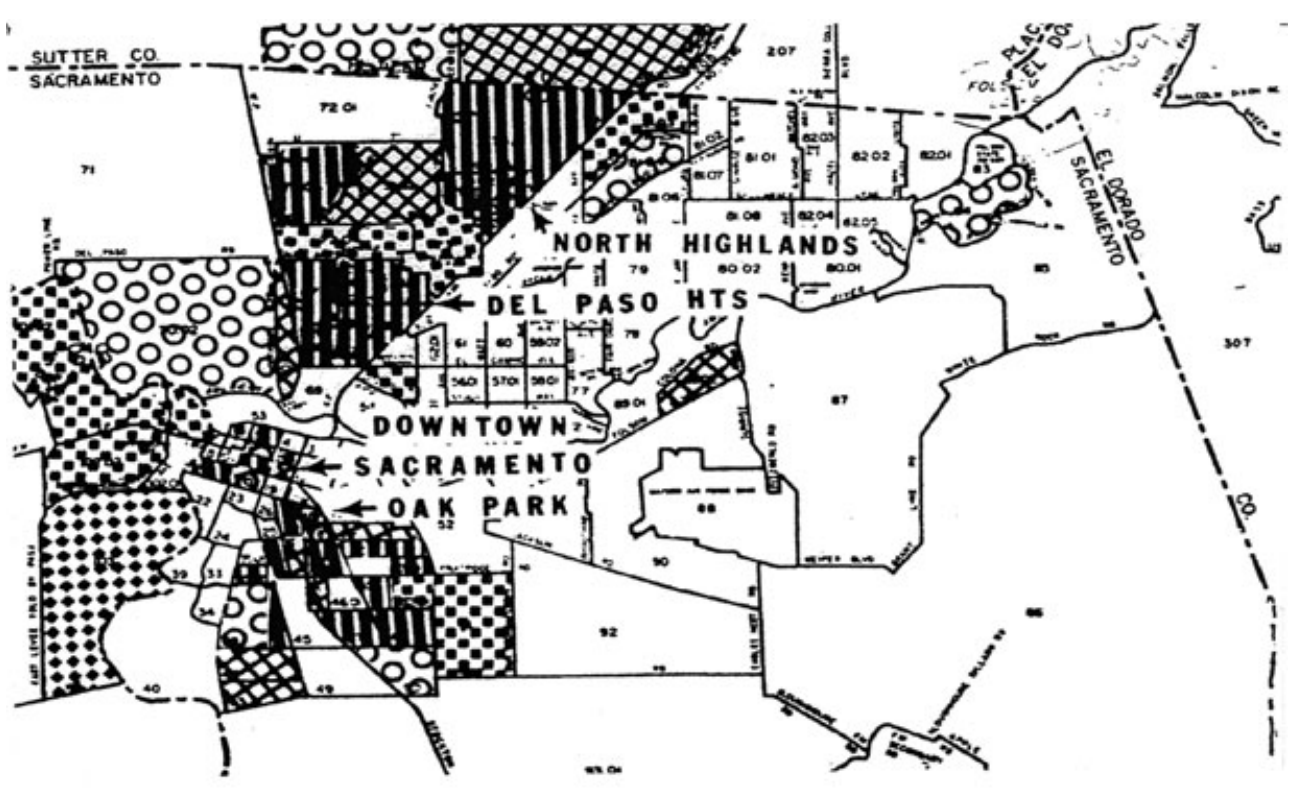

Non-residential tracts with loan volume of $10-25 \%$ of MSA avg. Residential tracts with loan volume of $10-25 \%$ of MSA avg.

Non-residential tracts with loan volume less than $10 \%$ of MSA avg. IIIII Residential tracts with loan volume less than $10 \%$ of MSA avg.

Figure 2 Mortgage deficient areas in Sacramento in 1974 (source: California Department of Savings and Loan Fair Lending Report No. 1, Vol. II, 1977)

By the 1970s, redlining was an accepted practice in Sacramento neighborhoods experiencing rapid integration. During the summer of 1969, racial tensions between white and black residents, fueled in part by housing discrimination, led to civil unrest and riots in the Oak Park community mirroring similar episodes of violence in cities across the US. Working from the success of national grassroots campaigns in the 1970s by coalitions such as the Association for Community Reforms Now (ACORN), the National Association for the Advancement of Colored People (NAACP), the National Urban League, and the National Training and Information Center, local groups such as the Sacramento Urban League, and regional advocacy by the NAACP and the Western Center on Law and Poverty pushed for formal administrative action on the area's housing problems. These coordinated multi-scaled advocacy efforts led to a series of local and statewide public hearings to address the lack of housing credit and the continued neglect of predominantly non-white neighborhoods by savings and loan corporations throughout the city and the state (California State Legislature, 1976).

Hearing testimony revealed how lenders associated the growing numbers and concentrations of non-whites in certain communities with increased financial risk to mortgage funders. The hearings led to investigations by the Department of Savings and Loan (DSL) that subsequently identified 'mortgage deficient areas' in Sacramento and in other major California cities (State of California, 1977). Figure 2 displays the DSL findings for Sacramento and shows how redlining in 1975 was concentrated in the northern and southern parts of the county undergoing racial integration, areas that over time became economically and socially unstable from financial disinvestment.

During this period long-standing segregationist housing policies, coupled with the actions of real estate professionals, worked to safeguard and maintain Sacramento's existing racial boundaries while creating new racial boundaries for housing credit. Thus, the racially oriented organization of the city's social, political and economic actions 
resulted in resettlements that reinforced racial segregation and relations of powerlessness that immobilized certain groups and constrained their free market participation (Iglesias, 2000).

\section{Redlining phase III: deregulation and the subprime mortgage market (1980-2004)}

State policy-makers, responding to the push by institutional lenders and banks for federal deregulation of lending activity, unknowingly laid the foundation for the subprime market crisis we see today under the guise of opening credit opportunities to financially starved redlined neighborhoods. As we shall see, lending deregulation provided the market conditions necessary for disparate lender activity in low-income, racialized neighborhoods while institutionalizing the subprime mortgage industry. Thus, a series of what appeared to be abstract administrative financial regulations actually had very localized implications.

In 1980, the Depository Institutions Deregulatory and Monetary Control Act eliminated all usury controls on first lien mortgage rates, permitting lenders to charge higher interest rates to borrowers with presumed higher credit risks. Subsequently, the Alternative Mortgage Transaction Parity Act of 1982 permitted the use of variable interest rates and balloon payments while specifically overriding local government restrictions on alternative lending products. Together, these regulatory changes encouraged the development and use of credit scoring in the mortgage arena to better gauge risk and enabled lenders to establish price differentials (interest rates) for higherrisk borrowers (Gramlich, 2004). Rather than just rejecting high-risk applicants with poor credit as in the prime mortgage market, lenders could now select loan terms that reflected their exposure to risk by adjusting interest rates and loan fees, and imposing balloon payments. This concept, better known as risk-based pricing, led to the use of credit scoring - a process that predicts the probability of default by borrowers (Meister, 1997). ${ }^{9}$

Standardized credit scoring became an industry standard when in 1995 the Federal National Mortgage Corporation (Fannie Mae) and the Federal Home Loan Mortgage Corporation (Freddie Mac) encouraged mortgage lenders to use credit scoring on loans submitted for purchase by these agencies. When 'Fannie' and 'Freddie' moved to automated loan underwriting, credit scoring became a requirement for determining whether a loan was eligible for sale to these agencies (Meister, 1997). Credit scoring subsequently became a critical part of the securitization boom as private mortgage insurance companies and non-agency mortgage purchasers followed the trend of standardizing risk assessment, a condition critical for creating new mortgage-based products such as Mortgage Backed Securities (MBSs). These new securities featured varying maturities issued according to different risk characteristics identified by credit scoring models used to predict loan pool performance (Office of the Comptroller of the Currency, 1997).

The demand for subprime mortgage products also increased when the Tax Reform Act of 1986 (TRA) eliminated the interest deduction for consumer credit. Homeowners quickly moved to consolidated consumer debt by refinancing home mortgages and taking advantage of interest deductions lost in TRA. Consequently, high-cost mortgage debt became cheaper than consumer debt (Chomsisengphet and Pennington-Cross, 2006). The TRA also created the Real Estate Mortgage Investment Conduit (REMIC) to promote the issuance of MBSs. The REMIC provided MBS investors with the option of selecting the level of credit risk and the accompanying rate of return and attracted a new pool of secondary market investors to purchase subprime-mortgage-backed securities.

9 See also Wyly et al. (2009, this issue) for a more detailed discussion on risk-based pricing. 
The 1980s signaled the formalizing of the subprime market and a dramatic shift in the mortgage industry away from the traditional fixed rate loan to nontraditional loans such as adjustable rate mortgages (ARMs) (Gruenberg, 2007). Federal responses to the housing finance industry's push to create new opportunities for profit produced policies that removed mortgage interest rate limits, facilitated the use of adjustable interest rates and enhanced opportunities for recycling mortgage funds via securitization. The state, therefore, assumed an active and important role in establishing the necessary market conditions for rapid subprime growth. The combination of ARMs, relaxed underwriting guidelines and steady pools of lending capital made available through securitization, intensified both investor activity in the MBS market and consumer use of subprime products. $^{10}$

Subprime loan originations rose $25 \%$ per year during the period 1994-2003, nearly a tenfold increase in just 9 years (Gramlich, 2004). In 2001, subprime mortgages accounted for $5 \%$ of total mortgage originations but by 2006, accounted for over $20 \%$ (Gruenberg, 2007). In 2003, the Federal Reserve Board (FED), monitoring the steady rise in subprime lending activity, became aware of deteriorating credit standards used by lenders in approving loan applications. The FED then collected data that clearly indicated lenders had eased lending standards by 2004 (Dodd, 2007). Congressional Hearing testimony further revealed that despite these early warning signs of subprime market problems, the FED in February 2004 actually promoted the use of ARMs and encouraged lenders to develop and market alternative ARM products while the FED was preparing to raise short-term interest rates (ibid.). Shortly thereafter, the FED raised interest rates 17 times, taking the FED funds rate from $1 \%$ to $5.25 \%$, overlooking the fact that the steady increase would soon trigger a massive reset of ARM interest rates in 2006 and 2007.

Fueling the demand for subprime mortgages were low start rates and loose credit guidelines making them more attractive than traditional fixed rate mortgages. In June 2005, former FED chair Alan Greenspan warned that $25 \%$ of loans originated were 'interest only' (ibid.). By 2006, the lax underwriting guidelines used for subprime mortgages became alarmingly clear as over $40 \%$ of loan approvals did not consider the applicant's income (Western Asset, 2007). In 2005 and in 2006, annual subprime loan volume ballooned to well over $\$ 600$ billion (Schloemer et al., 2006). Thus, federal regulators actually set the stage for the intense subprime activity that occurred during the period 2003-06.

But this rapid growth also came with problems. Community activists discovered that a large portion of subprime loan activity throughout the US was concentrated among black and Latino borrowers (Bradford, 2002; ACORN, 2004), and in the neighborhoods in which they live (Wyly et al., 2006). National organizations such as ACORN, the National Fair Housing Alliance, the Center for Responsible Lending and the National Community Reinvestment Coalition pressured Federal regulators while aiding local affiliates in organizing public awareness efforts. This combination of local and national level advocacy resulted in Federal acknowledgement of subprime loan concentration as early as 2000 (US Department of Housing and Urban Development, 2000). In 2006, the FED, relying on HMDA data from 2005, revealed that $55 \%$ of blacks and $46 \%$ of Latinos received subprime loans with interest rates exceeding the Treasury rate by 3 percentage points (Avery et al., 2006). Despite this information and intensive advocacy efforts that conveyed the disparate impact of subprime lending in minority neighborhoods, Federal regulators refused to take the necessary steps to head off the looming foreclosure crisis.

In Sacramento, the first signs of subprime loan concentration appeared in 2000 when ACORN organized 'sit-in' protests by borrowers in local branches of the Household Finance Corporation, one of the largest subprime originators in the area (Casa, 2000). Advocacy efforts also focused on local and state regulators. In 2001, the California Reinvestment Coalition (CRC) identified Sacramento as one of the major cities in

10 See also Gotham's (2009) more detailed discussion on securitization in this issue. 
California experiencing racial and spatial subprime loan concentration. Meanwhile, ACORN worked with city council members in drafting a resolution that would prohibit the city from doing business with any financial organization having ties to those engaged in predatory lending (Jones, 2001). The persistent efforts of housing activists revealed how the demographic targeting of non-white neighborhoods by subprime lenders and the exploitative terms of their credit resulted in dangerous subprime loan concentrations in Sacramento neighborhoods well before the housing crisis of 2007 occurred (CRC, 2001; ACORN, 2004).

The area's real estate boom beginning in 2000 also aided the racial concentration of subprime loans. The influx of investors and new residents from the San Francisco Bay Area and other California areas seeking affordable housing created a rush on Sacramento property. Recent estimates suggest that San Francisco Bay Area buyers purchased up to $40 \%$ of new homes in the Elk Grove and Natomas communities (Sadovi, 2005). Sacramento soon became one of the least affordable US real estate markets (Woolsey, 2007). Home prices quickly inflated throughout the entire region, even in areas concentrated with non-white residents, making home buying more difficult for all.

Consistently low FHA maximum loan limits failed to keep pace with the area's escalating home prices and accelerated the demand for subprime loans. Moreover, FHA mortgages usually consisted of fixed rate loans with high credit requirements, thus making 'teaser rate' adjustable loans and the low- or no-income requirements of many subprime loan products significantly easier to qualify for than FHA loans. ${ }^{11}$ For many, subprime financing became the only way to participate in the housing market. However, as we shall see, in Sacramento, subprime loan activity remained concentrated in areas previously redlined and shaped by state-sponsored segregation.

\section{Spatial comparisons}

In the US, we know that the use of subprime loans is higher for black and Latino borrowers than for whites, and also for black and Latino neighborhoods than for white ones (Wyly et al., 2006; 2009). As expected, 2004 HMDA data show similar patterns of subprime activity in Sacramento. But not well known is how the seemingly placeless economic and regulatory functions associated with contemporary housing credit markets remain linked to spaces shaped by historically racialized housing policy. To demonstrate the relationship between longstanding spatial patterns of racial segregation and contemporary housing policy, I map the geographic history of racialized space and housing policy. Figure 3 summarizes the geography of racialized space in Sacramento by overlaying census tracts redlined by lenders during the 1970s with census tracts that used racially restrictive covenants, providing an image of how housing policy shaped the Sacramento social and physical landscape. Historical patterns of redlining appear in the northern and southern parts of the city while areas with restrictive covenants show a west to east geography.

Figure 4 shows the percentage of loan denials by census tract. Wyly et al. (2006) found that loan applicants who are denied are 5 times as likely to approach a subprime lender. Therefore, denials could conceivably provide some evidence of increased subprime activity as well as of neighborhoods excluded from the prime mortgage market. Figure 4 shows that the geography of loan denials in Sacramento bears a strikingly similar pattern to the geography of redlined areas and racially restrictive covenants identified in Figure 3. Redlined neighborhoods located to the north and south of the central business district contain the highest proportion of loan denials. Also, high concentrations of loan denials appear near former military installations where

11 The author's review of HMDA raw data for Sacramento County shows that FHA loans accounted for only $1.13 \%$ of total loan activity for 2004 and only $1.58 \%$ of loan activity during the period $2003-6$. 


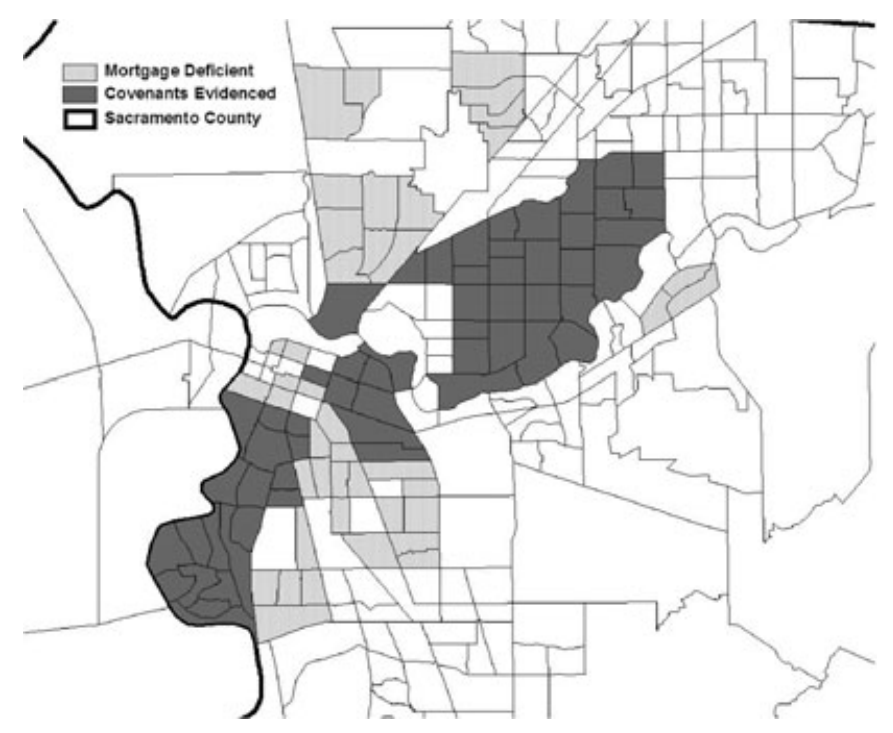

Figure 3 Preliminary map of areas with racially restrictive covenants and mortgage deficient areas in Sacramento (source: author's review of public records)

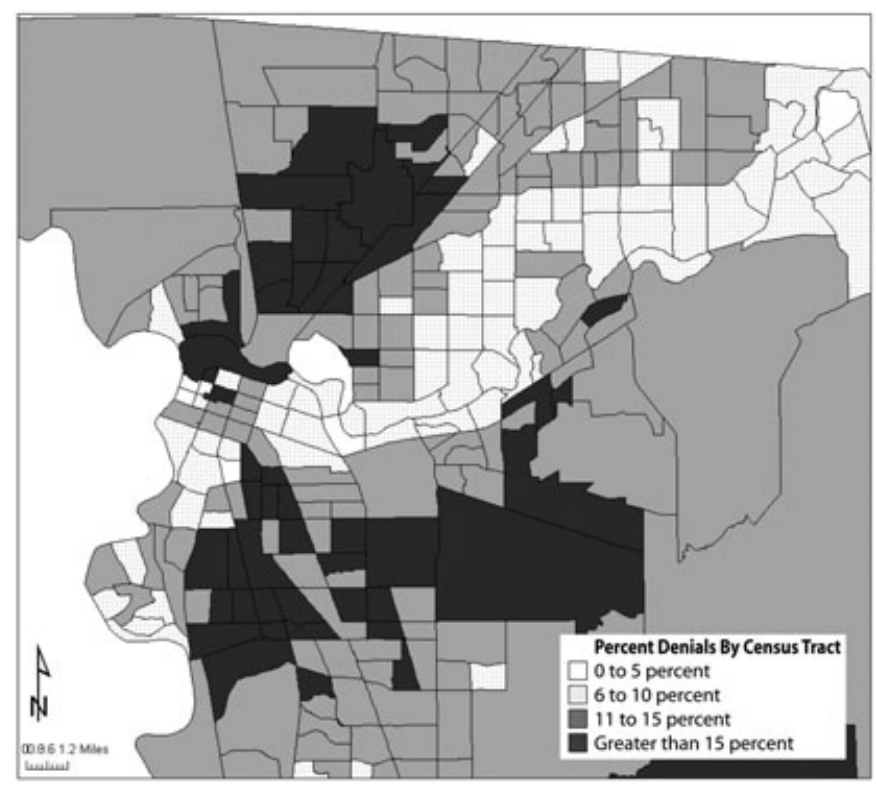

Figure 4 Percentage of loan denials by census tract for Sacramento County in 2004 (source: FFIEC HMDA raw data, 2004)

concentrations of non-whites formed during the period 1950-70. Conversely, census tracts with racially restricted covenants and those areas previously protected by private actions in the northeast area of the county incurred significantly lower rates of loan denials.

Finally, Figure 5 shows the percentage of subprime loan activity by census tract and clearly indicates that neighborhoods with a history of restricted access to lending products, or redlined areas, received a disproportionate share of subprime loans. A 


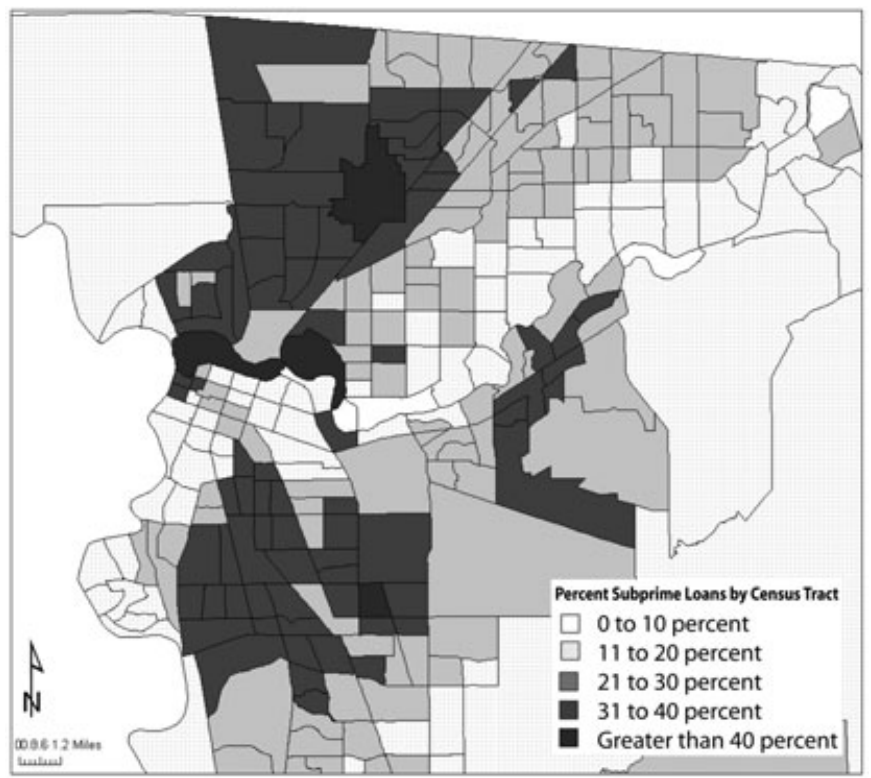

Figure 5 Percentage of subprime loans by census tract for Sacramento County in 2004 (source: FFIEC HMDA raw data, 2004)

critical point here is that newer development (between 1960 and 1980) located in areas without racially restrictive covenants also shows high concentrations of subprime activity in addition to high loan denial rates. These integrated housing tracts experienced significant economic decline during the redlining of the 1970s and remain unstable to this date. South Sacramento, an area highly populated with low-income and non-white residents, serves as a prime example of this decline.

But suburban tracts with restrictive covenants built during the same period and adjacent areas to the northeast previously protected by the actions of realtors show a much lower rate of subprime usage and loan denials. Similarly, we can see that subprime loan distribution in these tracts approximates the geography shaped by housing policies captured in Figure 3. The data show that census tracts with racially restrictive covenants today experience a lower rate of subprime activity than non-protected communities (tracts without racially restrictive covenants). Hence, this spatial comparison provides some evidence that access to mortgage financing remains consistently positive for neighborhoods over time once restraints on residency are in place. Moreover, census data confirm that neighborhoods with access to suitable housing credit have remained economically stable and for the most part racially homogeneous since 1950 . Conversely, the higher rate of subprime financing in tracts without restrictive covenants means those property owners incur higher risks, pay a higher price to finance the purchase of their home and have more difficulty accessing their equity when seeking financial and social mobility.

We have yet to see the full effects of high-cost subprime lending in Sacramento. The expansion of subprime mortgage products occurred at a time when interest rates were at their lowest while housing prices were at record highs. A good portion of these recently obtained ARMs have reached their first adjustment date. As these ARMs adjusted upward and area housing prices declined 44\% from 2005 values, homeowners faced higher loan-to-value ratios and encountered difficulty in refinancing their mortgages, especially when applying for a fixed rate loan. ${ }^{12}$ 
The sudden loss in equity from declining values coupled with higher mortgage payments means we now see higher rates of payment delinquencies, mortgage defaults, lender repossessions, 'short sales' and foreclosures in areas with concentrations of subprime loan activity. ${ }^{13}$ In fact, South Sacramento neighborhoods currently experience some of the highest foreclosure rates in the US (Christie, 2007). As property values decline in these neighborhoods, homebuyers looking to establish a sense of community and earn equity are less inclined to purchase in unstable locations. Neighborhood renters, the most likely to buy in distressed areas, are unable to afford the purchase of foreclosed property without the use of subprime loans or down payment assistance programs, two resources now with limited access due to the declining investor market for subprime MBSs and recent changes to FHA loan programs. Consequently, the resale inventory for foreclosed property is high, resulting in declining values, opportunities for investors and speculators, and leaves neighborhoods vulnerable to even further decline.

The economic and social costs of subprime related foreclosures to homeowners, neighborhoods and the city are indeed substantial. The California Reinvestment Coalition (2008) estimates Sacramentans experiencing foreclosure in 2007 collectively lost nearly $\$ 54$ million in addition to losing their homes. Census tracts with $45 \%$ or more minority residents accounted for almost $40 \%$ of this loss. ${ }^{14}$ The CRC also estimates a loss of $\$ 40$ million to the city in 2007 foreclosure-related administrative costs such as decreased property tax revenues. Finally, Global Insight (2007) estimates a \$1.73 billion loss in Gross Municipal Product for Sacramento due to the dramatic increase in foreclosures. Again, much of this loss can be attributed to the high rate of foreclosures in predominately minority neighborhoods. So we can see how concentrated subprime loan activity mirrors the destructive disinvestment practices characteristic of earlier episodes of redlining in the city.

The social costs of foreclosure also weigh heavily on these neighborhoods. Reduced property tax revenues means less funding for low-performing schools where foreclosures are concentrated. Support staff for local council members report that blight from boarded and vacant homes encourages 'squatters' and facilitates illicit drug sales, which in turn escalate violent crime. Squires and Kubrin (2006) note that an important relationship between neighborhood characteristics and crime involves homeownership and housing credit opportunity. They find that as the total loan amount in a neighborhood increases, crime rates tend to decrease. Simply stated, crime rates are lower in neighborhoods where homeownership is high. Consequently, the residential instability that subprime lending and foreclosures bring to a neighborhood also means a heavy social cost.

\section{Conclusion}

Subprime lending, a seemingly placeless and colorblind market phenomenon, plays an important but potentially divisive role in reorganizing space initially shaped by racebased housing policies. We now can see that the combination of historical and contemporary housing policies created a set of structural conditions in neighborhoods that made them vulnerable to capital extraction and the resulting economic catastrophes brought on by the meltdown of the globally leveraged deregulated subprime loan industry in 2007. As the patterns of foreclosures in Sacramento begin to mirror subprime activity, these vulnerabilities clearly produce racially disparate social and economic outcomes for residents of cities experiencing stress and change.

13 Using raw foreclosure data from DataQuick, the author calculates that $57 \%$ of foreclosures in Sacramento between January 1997 and June 2008 occurred within the 18 month period from January 2007 to June 2008.

14 Author's calculation using CRC methodology, 2006 Federal Financial Institutions Examination Council Census Estimates and DataQuick raw foreclosure data for 2007. 
This analysis of subprime loan activity demonstrates how socially and politically produced market interventions shape the life chances of residents and their communities. The evidence shows that race and geography influenced capital flows in a way that cannot be explained by traditional neoclassical market forces. The relationship between capital flows and geography in Sacramento leads to three hypotheses on how space was allocated in the city: (1) the use of racial categories in market interventions created structural conditions that dictated a specific course for market operations, laying the foundation for markets to operate as a form of exclusion as well as a form of extraction; (2) housing markets are embedded in adverse social relationships - therefore, economic activity today is somewhat shaped by social influences rather than simply the result of consumer market adaptation; and (3) although restrictive covenants, redevelopment, redlining and subprime lending appear to be distinct and separate processes, local geography links them as one intergenerational practice that racializes market outcomes. Hence, race plays a historical as well as a contemporary role in the way housing markets shape cities. We can see, as M.P. Smith (1988) reminds us, that economic forces work through historically, geographically and racially specific social and political processes. Markets, contends Smith, do not operate in isolation from government policy. Although theoretical 'supply and demand' markets are colorblind, real markets remain race-minded.

The fact that contemporary lending patterns in Sacramento are tied to past housing practices that shaped the social geography of the city shows how subprime lending continues historical practices of exclusion. We need to pay more attention to how past practices and public policies shape and influence markets. This will help us understand how markets operate as extensions of social and political processes and identify the embeddedness of social relations in allocating public resources. Social and economic inequities must not be seen as solely the result of free market practices and individual deficiencies. As we continue to rely on market practices to solve problems of urban planning and fix racialized inner-city space, we must recognize how urban policy implemented through market structures can perpetuate inequality in the US. The way we regulate and control access to housing credit sets the conditions for who wins or loses in our cities.

Jesus Hernandez (Jchernandez@ucdavis.edu), Department of Sociology, University of California, Davis, One Shields Drive, Davis, CA 95616, USA.

\section{References}

ACORN (Association of Community Organizations for Reform Now) (2004) Separate and unequal: predatory lending in America. ACORN Fair Housing [WWW document]. URL http://www.acorn.org/ fileadmin/Community_Reinvestment/ Reports/S_and_E_2004/separate_and_ unequal_2004.pdf (accessed 10 May 2009).

Avella, S. (2003) Sacramento, indomitable city. Arcadia Publishing, San Francisco.

Avery, R., K. Brevoort, and G. Canner (2006) Higher-priced home lending and the 2005 HMDA data. Federal Reserve Bulletin, 92 (September), a123-26.

Babcock, F. (1932) The valuation of real estate. McGraw-Hill, New York.
Bonilla-Silva, E. (1997) Rethinking racism: toward a structural interpretation. American Sociological Review 2, 465-80.

Bradford, C. (2002) Risk or race? Racial disparities and the subprime refinance market. Neighborhood Revitalization Project, Center for Community Change [WWW document]. URL http://www. knowledgeplex.org/showdoc.html?id=1032 (accessed 10 May 2009).

Cain, L. (1964) Absolute discretion? The California controversy over fair housing laws. Research Bulletin No. 7, April. Sacramento Committee for Fair Housing, Sacramento.

Calem, P., J. Hershaff, and S. Wachter (2004) Neighborhood patterns of subprime 
lending: evidence from disparate cities. Housing Policy Debate 15.3, 603-22.

California State Legislature (1976) Summary of interim hearings: redlining in California. Senate Local Government Committee, October 1976, State of California Library, Sacramento.

CRC (California Reinvestment Coalition) (2001) Stolen wealth: inequities in California's subprime market [WWW document]. URL http://calreinvest.org/ system/assets/16.pdf (accessed 10 May 2009).

CRC (California Reinvestment Coalition) (2008) Foreclosure trends in Sacramento and recommended policy options. [WWW document]. URL http://www.sacbee.com/ static/weblogs/real_estate/archives/ 287782904252008083324181.PDF (accessed 10 May 2009).

Campbell, J. and L. Lindberg (1990) Property rights and the organization of economic activity by the state. American Sociological Review 55.5, 634-57.

Casa, K. (2000) Preying on predators: nonprofits fight back against predatory lending practices. Sacramento News and Review, 23 August [WWW document]. URL http://www.newsreview.com/ sacramento/content?oid=3363 (accessed 10 May 2009).

Chomsisengphet, S. and A. Pennington-Cross (2006) The evolution of the subprime mortgage market. St. Louis Economic Review 88.1, 31-56.

Christie, L. (2007) Foreclosures drift to Sun Belt from Rust Belt. CNNMoney.com, 13 August [WWW document]. URL http:// money.cnn.com/2007/06/18/real_estate/ foreclosures_hardest_hit_zips/index.htm (accessed 10 May 2009).

Conley, D. (1999) Being black, living in the red: race, wealth, and social policy in America. University of California Press, Berkeley.

Creswell, J. (1998) Qualitative inquiry and research design: choosing among the five traditions. Sage Publications, Thousand Oaks.

Dodd, C. (2007) Opening statements: hearing on mortgage market turmoil. US Senate Committee on Banking, Housing and Urban Affairs. 22 March [WWW document]. URL http://banking.senate.gov/ public/index.cfm?FuseAction=Hearings. Hearing\&Hearing_ID $=4$ ccca4e6-b9dc- 40b1-bab5-137b3a77364d (accessed 10 May 2009).

Duff, E. (1963) Federal employee sues for blocked home. Sacramento Committee for Fair Housing, Sacramento.

Dymski, G.A. (2007) From financial exploitation to global banking instability: two overlooked roots of the subprime crisis [WWW document]. URL http:// www.soas.ac.uk/economics/events/crisis/ 43938.pdf (accessed 10 May 2009).

Farris, J. and C. Richardson (2004) The geography of subprime mortgage prepayment penalty patterns. Housing Policy Debate 15.3, 687-714.

Feagin, J. (1998) The new urban paradigm: critical perspectives on the city. Rowman and Littlefield, Boulder, CO.

Fligstein, N. (1996) Markets as politics: a political-cultural approach to market institutions. American Sociological Review 61.4, 656-74.

Freund, D. (2006) Marketing the free market: state intervention and the politics of prosperity in metropolitan America. In K. Kruse and T. Sugrue (eds.), The new suburban history, University of Chicago Press, Chicago.

Gelfand, M. (1975) A nation of cities: the federal government and urban America, 1933-1965. Oxford University Press, New York.

Girardi, K., A. Shapiro and P. Willen (2007) Subprime outcomes: risky mortgages, homeownership experiences, and foreclosures. Working Paper 07-15, Federal Reserve Bank of Boston [WWW document]. URL http://www.bos.frb.org/ economic/wp/wp2007/wp0715.pdf (accessed 10 May 2009).

Global Insight (2007) The mortgage crisis: economic and fiscal implications. November 2007 [WWW document]. URL http://www.globalinsight.com/Highlight/ HighlightDetail11078.htm (accessed 20 December 2008).

Gotham, K. (2002) Race, real estate and uneven development: the Kansas City experience 1900-2000. University Press of Kansas, Lawrence.

Gotham, K. (2006) The secondary circuit of capital reconsidered: globalization and the US real estate sector. American Journal of Sociology 112.1, 231-75.

Gotham, K. (2009) Creating liquidity out of spatial fixity: the secondary circuit of capital and the restructuring of the US 
housing finance system. International Journal of Urban and Regional Research 33. 2, 355-71.

Gottdiener, M. (1994) The social production of space. University of Texas Press, Austin.

Gottdiener, M. and R. Hutchinson (2006) The new urban sociology. Westview Press, Boulder, CO.

Gramlich, E. (2004) Remarks at the financial services roundtable annual housing policy meeting. Chicago, Illinois, 21 May [WWW document]. URL http://www. kc.frb.org/PUBLICAT/ECONREV/PDF/ 4q07Gramlich.pdf (accessed 12 May 2009).

Granovetter, M. (1985) Economic action and social structure: the problem of embeddedness. American Journal of Sociology 91, 481-510.

Granovetter, M., and R. Swedberg (eds.) (1992) The sociology of economic life. Westview Press, Oxford.

Gruenberg, M. (2007) Remarks to the American Banker's Association Stonier Graduate School. University of Pennsylvannia, 11 June [WWW document]. URL http://www.egrpra.gov/ news/news/speeches/archives/2007/ chairman/spjun1107.html (accessed 12 May 2009).

Harvey, D. (1985) The urbanization of capital: studies in the history and theory of capitalist urbanization. Johns Hopkins University Press, Baltimore.

Haynes, B. (2001) Red lines, black spaces. Yale University Press, New Haven.

Helper, R. (1969) Racial policies and practices of real estate brokers. University of Minnesota Press, Minneapolis.

Hoyt, H. (1933) One hundred years of real estate in Chicago. University of Chicago Press, Chicago.

Iglesias, E. (2000) Global markets, racial spaces and the role of critical race theory in the struggle for community control of investments: an institutional class analysis. Villanova Law Review 45, 1037-73.

Immergluck, D. and M. Wiles (1999) Two steps back: the dual mortgage market, predatory lending, and the undoing of community development. Woodstock Institute, Chicago.

Isidro, J. (2005) Images of America: Sacramento's Land Park. Arcadia, San Francisco.
Jackson, K. (1985) Crabgrass frontier: the suburbanization of the United States. Oxford University Press, New York.

Jones, S. (2001) Circling the sharks: legal opinions differ on whether Sacramento can ban predatory lending practices.

Sacramento News and Review 16 August

[WWW document] URL http:// www.newsreview.com/sacramento/ content?oid=8117 (accessed 10 May 2009).

Lax, H., M. Manti, P. Raca and P. Zorn (2004) Subprime lending: an investigation of economic efficiency. Housing Policy Debate 5.3, 533-71.

Logan, J. and H. Molotch (1987) Urban fortunes: the political economy of place. University of California Press, Berkeley.

Magagnini, S. (2005) Racist housing clauses stricken. The Sacramento Bee 13 January [WWW document]. URL http:// www.sacbee.clom/content.homes/re_news/ v-print/story/13553680p-14394400c.html (accessed 3 April 2007).

McMichael, S. and R. Bingham (1928) City growth essentials. The Stanley McMichael Publishing Organization, Cleveland.

Meister, L. (1997) What's the point of credit scoring? Business Review. Federal Reserve Bank of Philadelphia, September/October [WWW document]. URL http:// www.phil.frb.org/research-and-data/ publications/business-review/1997/ september-october/brso97lm.pdf (accessed 3 April 2007).

Mueller, P. (1966) Effects of housing discrimination on residential segregation patterns in Sacramento 1960-1966. The Sacramento Community Integration Project, Sacramento.

Mueller, P. and M. Crown (1965) McClellan Air Force Base area rental survey. Research Bulletin No. 9, Sacramento Committee for Fair Housing, Sacramento.

Newman, K. (2009) Post industrial widgets: capital flows and the production of the urban. International Journal of Urban and Regional Research 33.2, 314-31.

Office of the Comptroller of the Currency (1997) Asset securitization: comptroller's handbook, November 1997 [WWW document]. URL http://www.occ.treas.gov/ handbook/assetsec.pdf (accessed 4 April 2007).

Oliver, M. and T. Shapiro (1995) Black wealth/white wealth. Routledge, New York. 
Pulido, L. (2004) Environmental racism and urban development. In J. Wolch, M. Pastor $\mathrm{Jr}$ and P. Dreier (eds.), Up against the sprawl: public policy and the making of Southern California, University of Minnesota Press, Minneapolis.

Renuart, E. (2004) An overview of the predatory mortgage lending process. Housing Policy Debate 15.3, 467-502.

Sacramento City Planning (1950) Sacramento urban redevelopment: existing conditions in blighted areas. City of Sacramento, Sacramento.

Sadovi, M. (2005) Home buyers see value in Sacramento. Real Estate Journal.com. 20 July [WWW document] URL http:// www.realestatejournal.com/columnists/ livingthere/20050720-blueprint.html (accessed 12 May 2009).

Schloemer, E., W. Li, K. Ernst and K. Keest (2006) Losing ground: foreclosures in the subprime market and their cost to homeowners. Center for Responsible Lending, December [WWW document]. URL http://www.responsiblelending.org/ mortgage-lending/research-analysis/ foreclosure-paper-report-2-17.pdf (accessed 12 May 2009).

Smith, M.P. (1988) City, state and market: the political economy of urban society. Basil Blackwell, Oxford.

Squires, G. (ed.) (1989) Unequal partnerships: the political economy of urban redevelopment in postwar America. Rutgers University Press, New Brunswick.

Squires, G. (1994) Capital and communities in black and white: the intersections of race, class and uneven development. SUNY Press, Albany.

Squires, G. (ed.) (2002) Urban sprawl: causes, consequences, and policy responses. Urban Institute Press, Washington, DC.

Squires, G. (2005) Predatory lending: redlining in reverse. Shelterforce Online 139 [WWW document] URL http:// www.nhi.org/online/issues/139/ redlining.html (accessed 10 May 2009).
Squires, G., and C. Kubrin (2006) Privileged places: race, residence and the structure of opportunity. Lynne Rienner, Boulder, $\mathrm{CO}$.

State of California (1977) Department of Savings and Loan fair lending report No. 1, Vol. II. State of California Library, Sacramento.

Stuart, G. (2003) Discriminating risk: the US mortgage lending industry in the twentieth century. Cornell University Press, Ithaca.

US Department of Housing and Urban Development (2000) Unequal burden: income and racial disparities in subprime lending in America. [WWW document]. URL http://www.hud.gov/library/ bookshelf18/pressrel/subprime.html (accessed 12 December 2005).

Western Asset Management (2007) Subprime mortgages. Commentary/Insights 22 March [WWW document]. URL http:// www.westernasset.com/us/en/commentary/ subprime_mortgages_200703.cfm (accessed 10 May 2009).

Woolsey, M. (2007) Least affordable US real estate markets. Housing Trends, Forbes.com 23 July [WWW document]. URL http://www.forbes.com/2007/07/20/ unaffordable-housing-property-forbeslifecx_mw_0723realestate.html (accessed 10 May 2009).

Wyly, E., M. Atia, H. Foxcroft, D. Hammel and K. Phillips-Watts (2006) American home: predatory mortgage capital and neighborhood spaces of race and class exploitation in the United States. Geografiska Annaler B 88.1, 105-32.

Wyly, E., M. Moss, E. Kabiahizi and D. Hammel (2009) Cartographies of race and class: mapping the class-monopoly rents of American subprime mortgage capital. International Journal of Urban and Regional Research 33.2, 332-54.

Yin, R. (1994) Case study research: design and methods. Sage Publications, Thousand Oaks.

\section{Résumé}

Malgré des décennies de réformes gouvernementales, le système de crédit immobilier américain reflète toujours les anciens schémas de ségrégation raciale et d'inégalité. Conforme à cette logique, la crise du logement actuelle révèle une concentration étonnamment élevée de prêts hypothécaires à risque (subprime) et de saisies 
immobilières dans les quartiers résidentiels non-blancs du pays. Considérant l'hypothèse communément admise de la neutralité du marché, cette étude de cas sur les schémas de prêts à Sacramento (Californie) analyse les raisons pour lesquelles les transactions immobilières continuent à produire des résultats distinctifs au plan racial; elle identifie également les pratiques idéologiques dans lesquelles la race intervient, guide l'action économique de l'État et du secteur privé, et façonne les pratiques contemporaines sur le marché du crédit. 